\title{
Sputum cell counts and exhaled nitric oxide in patients with gastroesophageal reflux, and cough or asthma
}

\author{
Krishnan Parameswaran MD ${ }^{1}$, Christopher J Allen BM BCh ${ }^{1}$, Dennis Kamada PRCP ${ }^{1}$, \\ Ann Efthimiadis $\mathrm{MLT}^{1}$, Mehran Anvari MB PhD ${ }^{2}$, Frederick E Hargreave MD ${ }^{1}$ \\ Asthma Research Group, Departments of ${ }^{1}$ Medicine and ${ }^{2}$ Surgery, St Joseph's Healthcare \\ and McMaster University, Hamilton, Ontario
}

\begin{abstract}
K Parameswaran, CJ Allen, D Kamada, A Efthimiadis, M Anvari, FE Hargreave. Sputum cell counts and exhaled nitric oxide in patients with gastroesophageal reflux, and cough or asthma. Can Respir J 2001;8(4):239-244.
\end{abstract}

BACKGROUND: Gastroesophageal reflux (GER) is commonly associated with chronic cough and asthma, but there is little or no information on the nature of any associated airway inflammation.

OBJECTIVE: To observe whether the association with GER worsens airway inflammation in patients with chronic cough or asthma.

PATIENTS AND METHODS: The airway inflammatory indexes in induced sputum and exhaled air were examined in a cross-sectional study of 11 patients with cough and GER, nine patients with mildly symptomatic asthma and GER, nine patients with mildly symptomatic asthma without GER and nine normal, healthy control subjects. GER was shown objectively by $24 \mathrm{~h}$ ambulatory $\mathrm{pH}$ recording.

RESULTS: The sputum total cell count, the proportion of neutrophils and macrophages, and the fibrinogen level were normal in all four groups, with no significant differences among the groups. The sputum eosinophil and metachromatic cell percentages, and eosinophil cationic protein levels were normal in patients with cough and GER. They were significantly increased in patients with asthma compared with healthy subjects $(\mathrm{P}<0.01)$ and patients with cough $(\mathrm{P}<0.01)$, but were not different between groups with and without GER. Exhaled nitric oxide levels showed similar results $(\mathrm{P}<0.01)$. The correlations between the number of episodes of reflux and the proportion of sputum eosinophils, neutrophils or exhaled nitric oxide were modest but not significant.

CONCLUSIONS: GER, when associated with cough or mildly symptomatic asthma, does not cause or aggravate existing airway inflammation as measured by induced sputum cell counts and fibrinogen level, or by exhaled nitric oxide.

Key Words: Asthma; Chronic cough; Exhaled nitric oxide; Gastroesophageal reflux; Inflammation; Sputum cell counts

voir page suivante 


\section{Numération de cellules dans les expectorations et mesure de l'oxyde nitrique dans l'air expiré chez les patients souffrant de reflux gastro- oesophagien et de toux ou d'asthme}

CONTEXTE : Le reflux gastro-oesophagien (RGO) est souvent associé à la toux chronique ou à l'asthme, mais l'on sait très peu de choses, voire rien, sur la nature de l'inflammation des voies respiratoires en cause.

OBJECTIF : Vérifier si la présence de RGO aggrave l'inflammation des voies respiratoires chez les patients souffrant de toux chronique ou d'asthme.

PATIENTS ET MÉTHODE : L'indice d'inflammation des voies respiratoires a été mesuré dans les sécrétions obtenues par provocation et dans l'air expiré de sujets ayant participé à une étude transversale; l'échantillon comptait 11 patients présentant de la toux et du RGO, 9 patients souffrant d'asthme symptomatique léger et de RGO, 9 patients atteints d'asthme symptomatique léger mais pas de RGO et 9 sujets témoins normaux, en bonne santé. Le RGO a été confirmé objectivement par la mesure ambulatoire du $\mathrm{pH}$ sur 24 heures.
RÉSULTATS : Le nombre total de cellules dans les expectorations, la proportion de polynucléaires neutrophiles et de macrophages et le taux de fibrinogène se sont avérés normaux dans les quatre groupes, sans différence significative entre eux. Quant au pourcentage d'éosinophiles et de cellules métachromatiques dans les sécrétions et au taux de protéines cationiques éosinophiles, ils atteignaient des valeurs normales chez les patients atteints de toux et de RGO. Par contre, ces valeurs étaient significativement plus élevées chez les patients asthmatiques que chez les sujets en bonne santé $(\mathrm{P}<0,01)$ et les patients présentant de la toux $(\mathrm{P}<0,01)$, mais il n'y avait pas de différence entre les groupes souffrant ou non de RGO. Les mêmes remarques s'appliquent aux mesures de l'oxyde nitrique dans l'air expiré $(\mathrm{P}<0,01)$. Les corrélations établies entre le nombre d'épisodes de reflux et la proportion d'éosinophiles et de polynucléaires neutrophiles dans les sécrétions et l'oxyde nitrique dans l'air expiré se sont révélées modérées mais non significatives.

CONCLUSION : Le RGO associé à la toux ou à de l'asthme symptomatique léger n'entraîne pas d'inflammation des voies respiratoires ni n'aggrave celle-ci comme l'indiquent la numération des cellules et le taux de fibrinogène dans les expectorations obtenues par provocation ou la concentration d'oxyde nitrique dans l'air expiré.
$\mathrm{B}$ oth cough (1) and asthma (2) are commonly associated with gastroesophageal reflux (GER). The reflux of gastric contents into the esophagus is believed to cause cough and worsen asthma by a vagally mediated neurogenic reflex mechanism $(3,4)$, by microaspiration causing airway inflammation (5) or simply by an increase in ventilation (6). Airway neutrophilia $(7,8)$, eosinophilia $(9,10)$ and an increase in metachromatic cells (11) have been described in the sputum (7-9), bronchoalveolar lavage fluid (10) and mucosal biopsies (11) of patients with nonasthmatic cough and possible GER. Similar features are observed in patients with asthma (12). No human studies have examined airway inflammation in patients with asthma plus GER. Airway inflammation can also be examined by measuring the level of nitric oxide in exhaled air (13). We wanted to investigate whether GER in patients with cough or asthma is associated with the additional features of airway inflammation. We therefore examined the total and differential cell count, eosinophil cationic protein and fibrinogen levels in induced sputum, and nitric oxide in the exhaled air of patients with GER and nonasthmatic chronic cough or asthma, and compared them with those in control subjects or in patients with asthma without GER.

\section{PATIENTS AND METHODS}

Subjects: Nine healthy volunteers without GER, cough or asthma, 11 patients with nonasthmatic cough and GER, nine patients with asthma and GER, and nine patients with asthma but without GER were recruited consecutively from the Firestone Regional Chest and Allergy Clinic and the Gastro-Intestinal Motility Disorders Clinic, Hamilton, Ontario (Table 1). Asthma was identified by a history of episodic chest tightness, wheeze or breathlessness in the preceding 12 months, and by airway responsiveness to methacholine (provocative concentration required to produce a $20 \%$ fall in forced expiratory volume in $1 \mathrm{~s}$ of less than $8 \mathrm{mg} / \mathrm{mL}$ ). Nonasthmatic chronic cough was defined as cough for at least three months in the absence of symptoms of sinusitis, postnasal drip, relevant drug history and methacholine airway hyperresponsiveness. GER was defined as symptoms of heartburn, regurgitation or dysphagia, and a positive $24 \mathrm{~h}$ $\mathrm{pH}$ study (that is, a cumulative time of greater than $4 \%$ of the recording time in which the $\mathrm{pH}$ fell to below 4.0 at $5 \mathrm{~cm}$ above the manometrically determined lower esophageal sphincter during a $24 \mathrm{~h}$ period of continuous ambulatory dual-channel esophageal $\mathrm{pH}$ recording). All of the subjects had been nonsmokers for at least 12 months, and had normal chest and sinus radiographs. None of the subjects had had a respiratory tract infection within the four weeks preceding the study. Three patients with asthma with GER and two patients with asthma without GER were taking inhaled corticosteroids (400, 800 and 800 g budesonide daily, and 500 and $1000 \mathrm{~g}$ beclomethasone daily, respectively). Of the 20 patients with GER, one (with asthma) was being treated with ranitidine $150 \mathrm{mg}$ daily, and six (all with cough) were being treated with omeprazole $20 \mathrm{mg}$ daily (median duration 12 months). The study was approved by the Hospital Research Ethics Board, and all subjects gave written, informed consent.

Design and procedures: This was a cross-sectional study. The patients attended the laboratory on two or three days within a seven-day period. Patients with asthma withheld beta-agonists for $6 \mathrm{~h}$ before each visit. The seven patients with GER who were on antireflux treatment discontinued their medications for at least five days. On the first visit, asthma and cough symptoms were noted on a nine-point Likert scale (with a score of 9 indicating no symptoms). The exhaled air nitric oxide level was measured by a rapid, linear-response chemiluminescence analyzer (Sievers 240, USA) (13). The forced expiratory volume in $1 \mathrm{~s}$ and the slow 
TABLE 1

Characteristics of patients with cough and gastroesophageal reflux (GER), patients with mildly symptomatic asthma and GER, patients with mildly symptomatic asthma without GER and normal, healthy control subjects

\begin{tabular}{|c|c|c|c|c|}
\hline & Cough plus GER & Asthma plus GER & Asthma without GER & Control subjects \\
\hline Number & 11 & 9 & 9 & 9 \\
\hline Male (number) & 5 & 3 & 2 & 4 \\
\hline Mean age (years) & $45 \pm 17$ & $42 \pm 15$ & $32 \pm 13$ & $35 \pm 14$ \\
\hline Number of positive skin tests* & $1(2)$ & $4(8)$ & $8(6)$ & $1(2)$ \\
\hline \multicolumn{5}{|l|}{ Symptom scores* } \\
\hline Cough & $5.0(3.0)$ & $8.5(2.7)$ & $8.0(3.0)$ & $8.2(1.5)$ \\
\hline Wheeze & $8.0(2.0)$ & $8.5(2.0)$ & $7.0(4.0)$ & $9.0(0.0)$ \\
\hline Chest tightness & $8.0(2.0)$ & $7.0(4.2)$ & $7.0(4.0)$ & $9.0(0.5)$ \\
\hline Shortness of breath & $8.0(3.0)$ & $7.5(1.3)$ & $8.0(2.0)$ & $9.0(0.0)$ \\
\hline Dose of inhaled corticosteroids ( $\mathrm{g} /$ day $)^{*}$ & $0(0)$ & $100.0(200)$ & $85.7(186)$ & $0(0)$ \\
\hline Dose of beta-agonist (puff/day) ${ }^{*}$ & $0(0)$ & $2.0(3.0)$ & $2.0(3.0)$ & $0(0)$ \\
\hline $\mathrm{FEV}_{1}(\mathrm{~L})$ & $3.0 \pm 0.8$ & $2.5 \pm 1.0$ & $3.0 \pm 0.5$ & $3.4 \pm 0.8$ \\
\hline $\mathrm{FEV}_{1}(\%$ predicted $)$ & $94.6 \pm 13.7$ & $76.0 \pm 17.4$ & $88.5 \pm 12.1$ & $99.0 \pm 7.4$ \\
\hline $\mathrm{PC}_{20}(\mathrm{mg} / \mathrm{mL})^{\dagger}$ & $63.1(3.1)$ & $0.5(9.7)$ & $0.12(2.5)$ & $50.1(5.0)$ \\
\hline \multicolumn{5}{|l|}{24 h pH study* } \\
\hline Cumulative time - LES, $\%$ & $6.3(11.8)$ & $5.8(2.5)$ & $1.0(1.9)$ & $2.4(2.0)$ \\
\hline Cumulative time - UES, $\%$ & $0.2(0.3)$ & $0.5(1.2)$ & $0.1(0.2)$ & $0(0.2)$ \\
\hline Number of refluxes - LES, $n$ & $86(229)$ & $67(12)$ & $16(45)$ & $45(36)$ \\
\hline Number of refluxes - UES, $n$ & $13(19)$ & $16(18)$ & $9(9)$ & $2(7)$ \\
\hline
\end{tabular}

${ }^{*}$ Median (interquartile range); ${ }^{\dagger}$ Geometric mean (geometric standard deviation). FEV 1 Forced expiratory volume in 1 s; LES Lower esophageal sphincter; $P C_{20}$ Provocative concentration required to produce a $20 \%$ fall in FEV $V_{1}$; UES Upper esophageal sphincter

vital capacity were then measured (14), and a methacholine inhalation test was carried out by the tidal breathing method (15). Bronchoconstriction was reversed with salbutamol, and sputum was induced with hypertonic saline selected from the expectorate and processed with $0.1 \%$ dithiothreitol (Sputolysin, Calbiochem Corporation, USA), as described by Pizzichini et al (16). Total and differential cell counts, including that of metachromatic cells, were conducted, and the supernatant was stored at $-70^{\circ} \mathrm{C}$ for fluid-phase measurements. The concentration of eosinophil cationic protein in the thawed supernatant was determined by radioimmunoassay (Kabi Pharmacia Diagnostics AB, Sweden) (limit of detection $2.0 \mathrm{~g} / \mathrm{L}$ ). The fibrinogen level was measured by a 'sandwich' enzyme-linked immunosorbent assay using a rabbit antihuman fibrinogen antibody (Dako A080, Dako Diagnostics Canada Inc, Canada) (limit of detection $0.79 \mathrm{mg} / \mathrm{L}$ ). All sputum measurements were made by investigators who were blinded to the clinical details.

All subjects attended the gastrointestinal motility laboratory either on the same day as or within five days of the first visit. The symptoms of GER were assessed using a validated questionnaire (17). An ambulatory dual-channel digitrapper (Medtronic-Synectics, Sweden) was used to perform $24 \mathrm{~h} \mathrm{pH}$ testing. The lower and upper $\mathrm{pH}$ electrodes were positioned $5 \mathrm{~cm}$ and $25 \mathrm{~cm}$, respectively, above the manometrically determined lower esophageal sphincter. The cumulative time (expressed as a percentage of the total recording time) during which the $\mathrm{pH}$ was below 4.0, and the number of episodes during which the $\mathrm{pH}$ fell to below 4.0, at the two electrodes were noted (18).

Statistical analysis: The clinical and demographic data were summarized using the appropriate descriptive statistics. Dif- ferences in sputum cell counts and exhaled nitric oxide levels between groups were analyzed using the general linear model procedure of SPSS (Advanced Statistics 10.0 for Windows, SPSS Inc, USA), adjusting for the dose of inhaled corticosteroids. The correlation between variables was examined by the Spearman rank correlation coefficient. The sample size for each group was calculated to show at least a twofold difference (which was considered clinically significant) in the mean values of the total cell count, and the neutrophil and eosinophil percentage differential counts with $80 \%$ power. $\mathrm{P}<0.05$ (two-sided) was considered statistically significant.

\section{RESULTS}

Sputum was obtained from all 38 subjects. The sputum total cell count, neutrophil and macrophage percentage differential counts, and fibrinogen levels were normal in all four groups, with no significant differences among the groups (Table 2 and Figure 1A). The eosinophil and metachromatic cell counts, and the level of eosinophil cationic protein, were normal in patients with cough and GER (Table 2, and Figures $1 \mathrm{~A}$ and $1 \mathrm{~B})$. They were significantly increased in patients with asthma compared with those in control subjects $(\mathrm{P}<0.01)$ and in patients with cough $(\mathrm{P}<0.01)$; however, there was no difference between the groups with and without reflux. The exhaled nitric oxide levels showed similar results $(\mathrm{P}<0.01)$ except that the levels were greater in patients with asthma without reflux than in those with reflux. This difference was not significant when adjusted for the dose of inhaled corticosteroid. There were no significant differences in the cell counts between patients with GER who were on acid-suppressive therapy and those who were 
TABLE 2

Sputum and exhaled nitric oxide measurements of patients with cough and gastroesophageal reflux (GER), patients with mildly symptomatic asthma and GER, patients with mildly symptomatic asthma without GER and healthy control subjects

\begin{tabular}{|c|c|c|c|c|}
\hline & Cough plus GER & Asthma plus GER & Asthma, no GER & Control subjects \\
\hline \multicolumn{5}{|l|}{ Cell counts } \\
\hline Viability, \% & $70.5(32.0)$ & $75.0(5.0)$ & $66.0(32.8)$ & $67.0(34.0)$ \\
\hline Squamous cells, $\%$ & $1.2(2.2)$ & $1.1(2.3)$ & $1.0(2.5)$ & $0.9(1.5)$ \\
\hline Total cell count, $10^{6} / \mathrm{g}$ & $3.4(2.6)$ & $3.4(2.3)$ & $3.5(6.6)$ & $2.1(3.4)$ \\
\hline Neutrophils, \% & $32.6(35.0)$ & $30.2(31.8)$ & $31.4(30.2)$ & $35.0(28.2)$ \\
\hline Eosinophils, \% & $0(0.3)$ & $1.3(5.0)$ & $2.6(8.1)$ & $0(0)$ \\
\hline Bronchial epithelial cells, \% & $0.1(0.5)$ & $0.3(0.5)$ & $0(0.9)$ & $1.0(1.5)$ \\
\hline Metachromatic cells, \% & $0(0)$ & $0.13(0.13)$ & $0.09(0.09)$ & $0(0)$ \\
\hline \multicolumn{5}{|l|}{ Fluid phase } \\
\hline Eosinophil cationic protein, $\mu \mathrm{g} / \mathrm{L}$ & $163(214)$ & $139(1490)$ & $613(990)$ & $156(178)$ \\
\hline Fibrinogen, ng/mL & $414(434)$ & $622(825)$ & $455(1946)$ & $400(391)$ \\
\hline
\end{tabular}

Numbers are median (interquartile range)
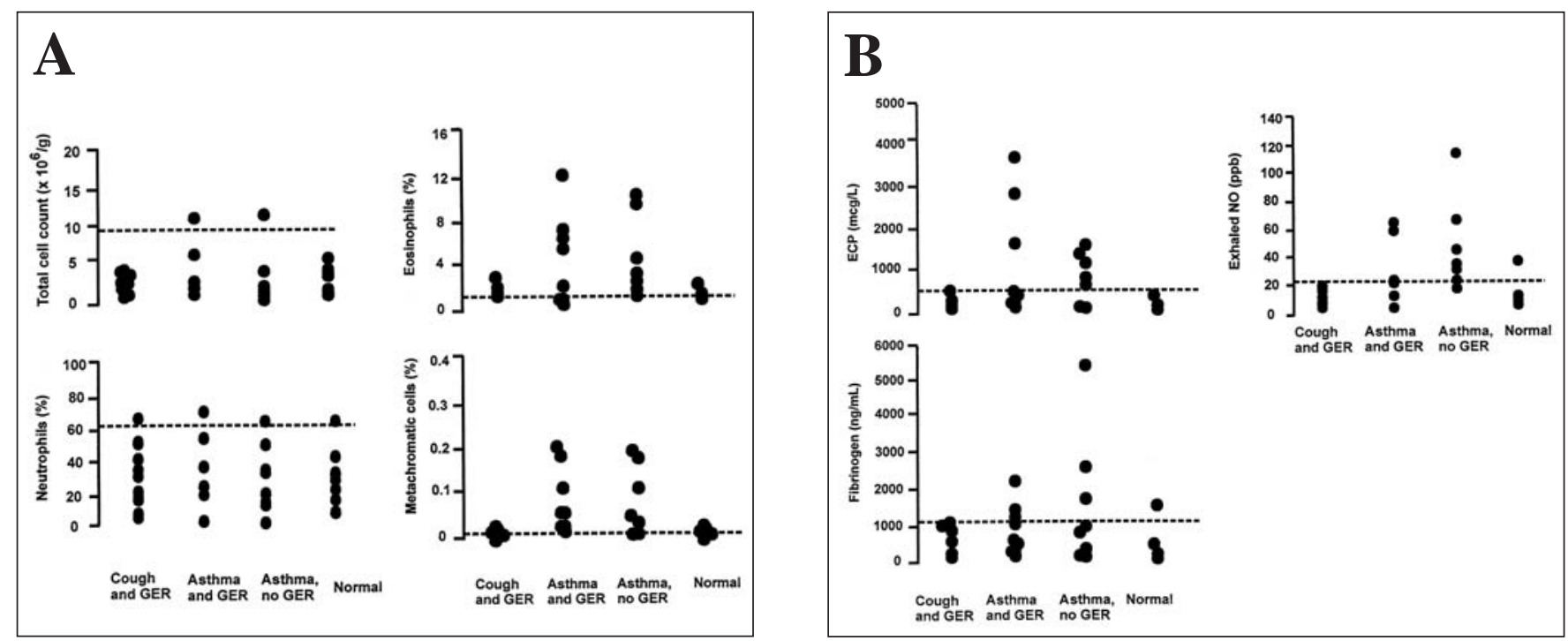

Figure 1) Inflammatory markers in sputum and exhaled air in patients with cough with gastroesophageal reflux (GER), asthma plus GER, asthma without GER and normal control subjects. The horizontal lines represent the upper limit of normal values (90th percentile) (23,25). A Total cell count, and neutrophil, eosinophil and metachromatic cell differential cell counts. B Fluid-phase eosinophil cationic protein (ECP), fluid-phase fibrinogen and exhaled nitric oxide (NO) levels. ppb Parts/billion

not on treatment. The correlations between the number of episodes of reflux to the lower and upper $\mathrm{pH}$ electrodes and the sputum eosinophil count ( $\mathrm{r}=-0.2$ and -0.1 , respectively), the neutrophil count $(\mathrm{r}=0.3$ and 0.2 , respectively) and the exhaled nitric oxide levels ( $\mathrm{r}=-0.2$ and -0.03 , respectively) were not statistically significant.

\section{DISCUSSION}

The results show that patients with GER who presented with cough did not have evidence of airway inflammation as measured by sputum cell counts and the level of exhaled nitric oxide. The patients with mildly symptomatic asthma and GER had an eosinophilic bronchitis compared with the control subjects; however, there was no difference in sputum cell counts or exhaled nitric oxide levels compared with the patients with asthma without GER. This suggests that the association with GER does not worsen the airway inflammation in patients with cough or mildly symptomatic asthma.

This is the first study examining the inflammation in induced sputum in which GER was also investigated by the measurement of the upper and lower esophageal $\mathrm{pH}$ in all subjects. The study reports two novel observations. First, in patients with objectively confirmed GER and chronic cough, 
there was no evidence of airway inflammation in sputum samples. This result is similar to that of Boulet et al (11) who did not find any increase in inflammatory cell number in the bronchoalveolar lavage fluid and bronchial mucosal biopsies in six patients with cough and objectively confirmed GER. It is different from the findings of Jatakanon et al (8) who observed sputum neutrophilia in four patients with nonasthmatic cough and GER, and from that of McGarvey et al (10) who showed an increase in bronchoalveolar lavage fluid eosinophils in seven patients with cough and GER. These differences may reflect differences in the intensity of the cough and GER, in the patient population (for example, a coincidentally associated eosinophilic bronchitis [19]) or in the airway compartment that was sampled. Second, evidence of airway inflammation was sought in the sputum of patients with asthma and GER, and was found not to be different from that of patients with asthma without GER. This suggests that the degree of GER present in these patients did not contribute to airway inflammation in asthma.

The study design was appropriate to examine the effect of GER on airway inflammation in patients with asthma. However, the design may be criticized on other issues. First, we did not have a group of patients with non-GER cough. Because we had excluded all of the conditions other than GER that can cause a cough, and because almost all idiopathic cough is due to GER (20), we did not, a priori, include a group of patients with non-GER cough. However, a retrospective analysis of the cell counts of five patients with chronic nonasthmatic cough who were screened to be included in the study and who had a normal $24 \mathrm{~h}$ esophageal $\mathrm{pH}$ study showed normal total cell counts with a median of $3.110^{6} / \mathrm{g}$ (interquartile range [IQR] 3.2), and a differential cell count of neutrophils of $21 \%$ (IQR 29) and of eosinophils of $0 \%$ (IQR 0.2). Second, we cannot confirm that the GER was responsible for the cough; however, it is the most likely cause because the cough either disappeared (one patient) or improved (five patients) after three months of antireflux therapy (no improvement in two patients, three patients did not return for review). Third, it can be argued that the GER was mainly confined to the lower esophagus with very few episodes of reflux to the hypopharynx, and, consequently,

\section{REFERENCES}

1. Irwin RS, Zawacki JK, Curley FJ, French CL, Hoffman PJ. Chronic cough as the sole presenting manifestation of gastroesophageal reflux. Am Rev Respir Dis 1989;140:1294-300.

2. Harding SM. Gastroesophageal reflux and asthma: insight into the association. J Allergy Clin Immunol 1999;104:251-9.

3. Wright RA, Miller SA, Corsello BF. Acid-induced esophagobronchial-cardiac reflexes in humans. Gastroenterology 1990;99:71-3.

4. Ing AJ, Ngu MC, Breslin AB. Chronic persistent cough and gastrooesophageal reflux. Thorax 1991;46:479-83.

5. Jack CIA, Calverley PMA, Donnelly RJ, et al. Simultaneous tracheal and oesophageal $\mathrm{pH}$ measurements in asthmatic patients with gastrooesophageal reflux. Thorax 1995;50:201-4.

6. Field SK, Evans JA, Price LM. The effects of acid perfusion of the esophagus on ventilation and respiratory sensation. Am J Respir Crit Care Med 1998;157:1058-62.

7. Pizzichini MM, Pizzichini E, Parameswaran K, et al. Nonasthmatic chronic cough: No effect of treatment with an inhaled corticosteroid in patients without sputum eosinophilia. Can Respir J 1999;6:323-30. little possibility of aspiration and airway inflammation. This needs to be studied specifically by measuring airway inflammation in patients with GER and oropharyngeal reflux. Fourth, acid-suppressive therapy is unlikely to have affected the sputum cell counts because there were no differences in the cell counts between patients on treatment and those not on treatment. Finally, methacholine inhalation is unlikely to have increased the frequency of reflux episodes (21) because the tests were done at least $24 \mathrm{~h}$ apart.

The implications of the results are twofold. First, the absence of neutrophilic inflammation suggests that microaspiration of acidic gastric contents may not be a major contributory factor in cough or asthma associated with GER. A vagal reflex mechanism associated with microvascular leakage (22) or an increase in ventilation (6), and mediated by kinins, may be more important. However, sputum fibrinogen, an indicator of vascular leakage, was normal in the present study. Although the level of exhaled nitric oxide was greater in patients with asthma without GER than in patients with asthma with GER, this difference was not significant when adjusted for the dose of inhaled corticosteroids. This result is consistent with a previous observation (23) that the exhaled nitric oxide levels of patients with asthma of different levels of 'control' may not be different if they are taking inhaled corticosteroids. Second, because GER did not worsen the airway inflammation in the patients with asthma, it is unlikely that increasing the doses of anti-inflammatory drugs will have additional clinical benefits in patients with asthma with GER (24). This needs to be evaluated prospectively.

\section{CONCLUSIONS}

In this cross-sectional study of patients with nonasthmatic cough or mildly symptomatic asthma associated with GER, there was no evidence of worsening of airway inflammation measured by sputum cell counts and levels of exhaled nitric oxide.

ACKNOWLEDGEMENTS: We thank Dr M Kelly, S Weston and S Carruthers-Elliott for the sputum measurements, and A Borm, $\mathrm{L}$ DiLuca and $\mathrm{S}$ Kislewski for the esophageal $\mathrm{pH}$ and motility measurements.

8. Jatakanon A, Lalloo UG, Lim S, Chung KF, Barnes PJ. Increased neutrophils and cytokines, TNF- and IL-8, in induced sputum on non-asthmatic patients with chronic dry cough. Thorax 1999;54:234-7.

9. Carney IK, Gibson PG, Murree-Allen K, Saltos N, Olson LG, Hensley MJ. A systematic evaluation of mechanisms in chronic cough. Am J Respir Crit Care Med 1997;156:211-6.

10. McGarvey LPA, Forsythe P, Heaney LG, MacMahon J, Ennis M. Bronchoalveolar lavage findings in patients with chronic nonproductive cough. Eur Respir J 1999;13:59-65.

11. Boulet L-P, Milot J, Boutet M, St Georges F, Laviolette M. Airway inflammation in nonasthmatic subjects with chronic cough. Am J Respir Crit Care Med 1994;149:482-9.

12. Bousquet J, Chanez P, Lacoste JY, et al. Eosinophilic inflammation in asthma. N Engl J Med 1990;323:1033-9.

13. Silkoff PE, McClean PA, Slutsky AS, et al. Marked flow-dependence of exhaled nitric oxide using a new technique to exclude nasal nitric oxide. Am J Respir Crit Care Med 1997;155:260-7.

14. American Thoracic Society. Standardization of Spirometry, 1994 Update. Am J Respir Crit Care Med 1995;152:1107-36. 
15. Juniper EF, Cockcroft DW, Hargreave FE. Histamine and Methacholine Inhalation Tests: A Laboratory Tidal Breathing Protocol, 2nd edn. Lund: Astra Draco AB, 1994.

16. Pizzichini E, Pizzichini MM, Efthimiadis A, Hargreave FE, Dolovich J. Measurement of inflammatory indices in induced sputum: effects of selection of sputum to minimize salivary contamination. Eur Respir J 1996;9:1174-80.

17. Parameswaran K, Allen CJ, Belda J, Anvari M. Reproducibility, validity, and responsiveness of a GERD specific symptom questionnaire. Gastroenterology 1999;116:A45-6. (Abst)

18. Kahrilas PJ, Quigley EM. Clinical esophageal $\mathrm{pH}$ recording: a technical review for practice guideline development. Gastroenterology 1996;110:1982-96.

19. Gibson PG, Hargreave FE, Girgis-Gabardo A, Morris M, Denburg JA, Dolovich J. Chronic cough with eosinophilic bronchitis: examination for variable airflow obstruction and response to corticosteroid. Clin Exp Allergy $1995 ; 25: 127-32$
20. Irwin RS, Madison JM. Anatomical diagnostic protocol in evaluating chronic cough with specific reference to gastroesophageal reflux disease. Am J Med 2000;108(Suppl 4a):126S-30S.

21. Moote DW, Lloyd DA, McCourtie DR, Wells GA. Increase in gastroesophageal reflux during methacholine-induced bronchospasm. J Allergy Clin Immunol 1986;78:619-23.

22. Hamamoto J, Kohrogi H, Kawano O, et al. Esophageal stimulation by hydrochloric acid causes neurogenic inflammation in the airways in guinea pigs. J Appl Physiol 1997;82:738-45.

23. Berlyne GS, Parameswaran K, Kamada D, Efthimiadis A, Hargreave FE. A comparison of exhaled nitric oxide and induced sputum as markers of airway inflammation. J Allergy Clin Immunol 2000;106:638-44.

24. Hargreave FE. Induced sputum and response to glucocorticoids. J Allergy Clin Immunol 1998;102:S102-5.

25. Belda J, Leigh R, Parameswaran K, O’Byrne PM, Sears MR, Hargreave FE. Induced sputum cell counts in healthy adults. Am J Respir Crit Care Med 2000;161:475-8. 


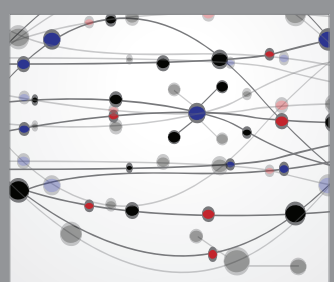

The Scientific World Journal
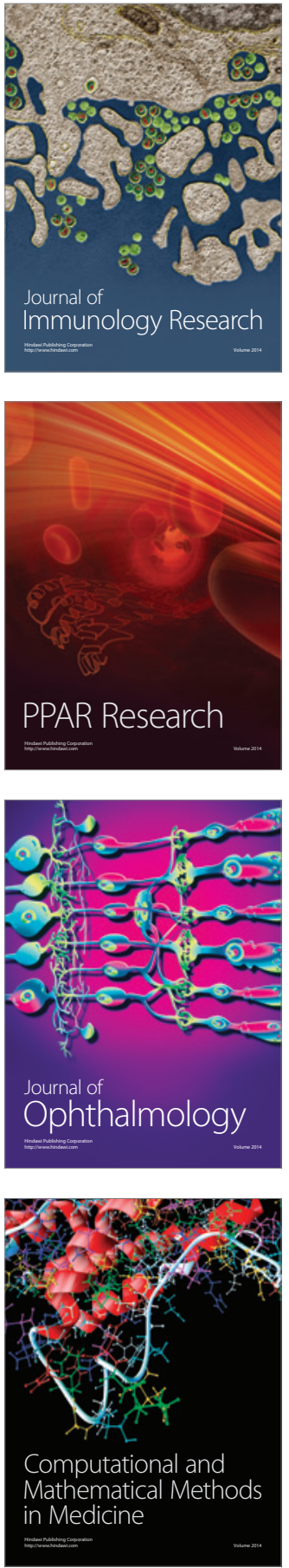

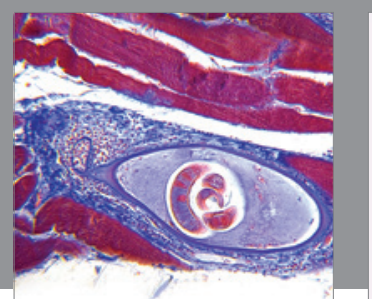

Gastroenterology Research and Practice

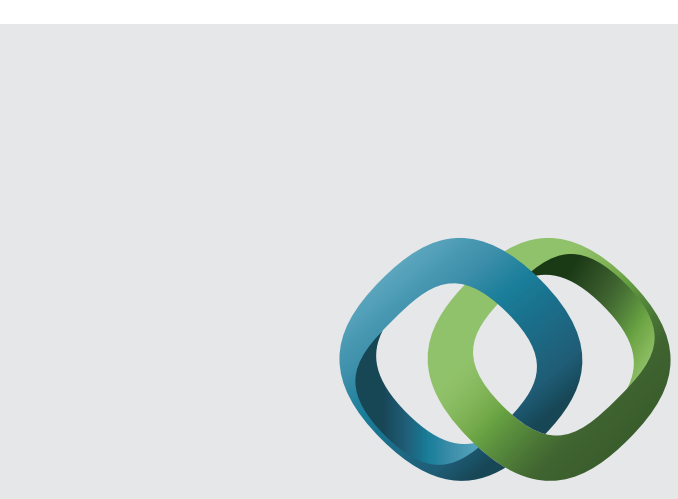

\section{Hindawi}

Submit your manuscripts at

http://www.hindawi.com
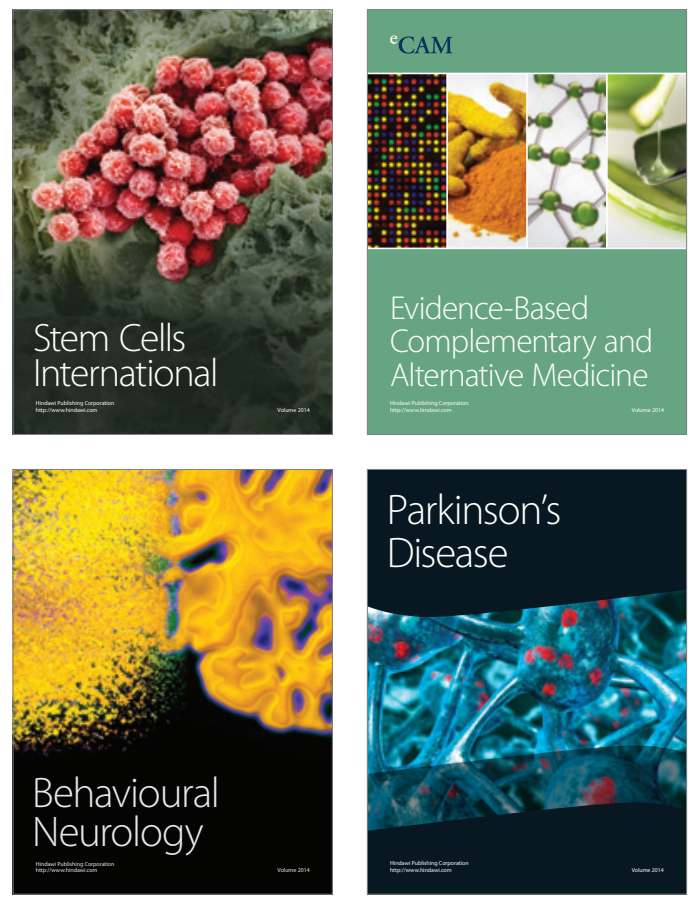
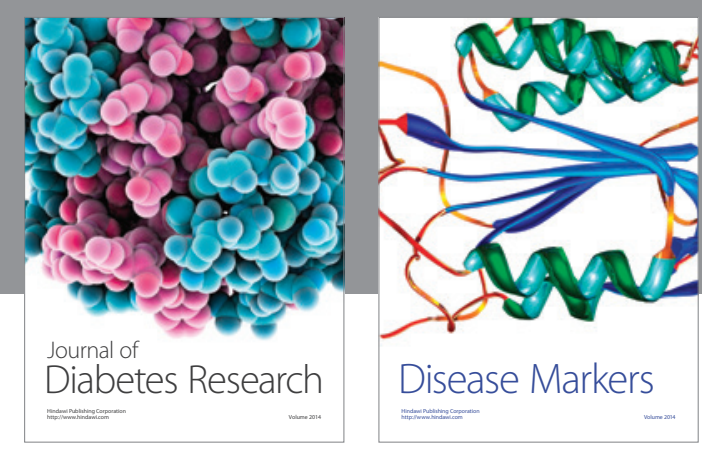

Disease Markers
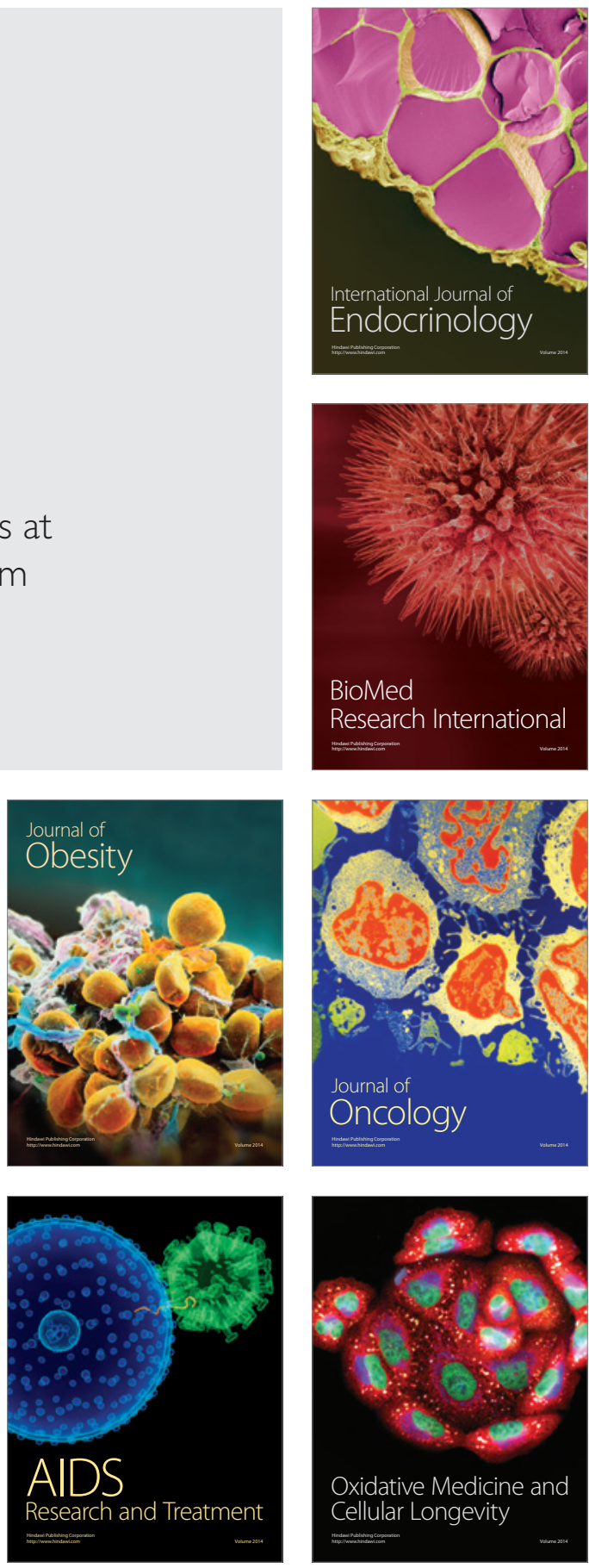